\title{
Methods of DNA isolation from poultry meal
}

\author{
M. Natonek-Wiśniewska ${ }^{1}$ and E. Słota \\ Department of Animal Immuno- and Cytogenetics, \\ National Research Institute of Animal Production \\ 30-083 Balice, Poland
}

(Received 1 June 2006; revised version 16 May 2007; accepted 6 September 2007)

\begin{abstract}
Legal regulations concerning BSE prevention stipulate a total ban on the addition of animal meals to the feed of animals whose meat is intended for consumption (Council Decision 2000/766/ EC). Council Regulation 1774/2002/EC allows the use of animal meals in non-ruminant feeds on the condition that the meals contain no material originating from the same species as the animals fed.

Poultry meals are an animal component whose use is allowed by the latter regulation. The standard method of animal component identification (using silica) was found to be effective for poultry and feather meals, but not for blood meal. Isolation of DNA from blood spots was unsuccessful. Only the use of a Sherlock kit enabled a PCR product to be obtained. The sensitivity of the identification method from poultry blood meal was shown to be $2 \%$. Analysis of poultry meal, feather meal and blood meal contaminated with bovine meal shows that the methods used for isolating DNA were effective.
\end{abstract}

KEY WORDS: poultry meal, feather meal, blood meal, BSE, PCR

\section{INTRODUCTION}

Methods for the identification of animal meals in feed mixtures have been the subject of many studies over recent years. These studies were motivated by the threat of BSE (Bovine Spongiform Encephalopathy) whose infectious agent (prion protein) can be transmitted orally through feed mixtures containing animal components.

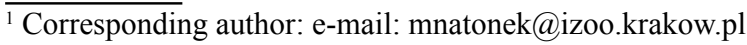


Several legal regulations concerning the feeding of compound feeds that contain animal meals have been adopted in an effort to prevent BSE. These regulations stipulate a total ban on the addition of meals to the feed of all animals whose meat is intended for consumption (Council Decision 2000/766/EC) or allow the use of meals in non-ruminants on the condition that the meals contain no material originating from the same species as the animals fed (Council Regulation 1774/2002/EC).

Poultry meal is an animal component whose use is allowed by the latter regulation. Because poultry meal may contain components from other species or be contaminated with other meals during production, it is necessary to test its composition. It is known that whole animals or just their feathers and blood can be used to produce poultry meal. Meals obtained in this way differ not only in protein content and protein availability to animals, but also in the type of analyses they require. It is therefore appropriate to test the usefulness of the standard method for identifying animal components and, if necessary, to find other efficient methods for testing poultry meals.

\section{MATERIAL AND METHODS}

Samples of poultry meal, feather meal and poultry blood meal sent for analysis to the Department of Animal Immuno- and Cytogenetics of the National Research Institute of Animal Production, were investigated. They served as a basis for three samples supplemented with $0.5 \%$ bovine meat-and-bone meal. In addition, a feed mixture without bovine meat-and-bone meal was used to make four samples containing $0.5,1,2$ and $4 \%$ blood meal. The positive control for the poultry component was a sample of hen DNA isolated from blood using a Wizard Kit (Promega), while a feed mixture containing bovine meat-and-bone meal served as a control for the bovine component. The negative control was a mixture without bovine meat-and-bone meal.

\section{Adjustment of isolation method to the type of poultry meal}

Central to this study was the isolation performed using the following three methods:

- silica,

- a Sherlock kit (A\&A Biotechnology) for identification of biological microtraces,

- a method used to isolate DNA from blood spots according to Słomski (2004).

The first method is a standard procedure for the isolation of DNA from feed mixtures. It uses guanidine thiocyanate $(\mathrm{GuSCN})$ buffer, a silicon dioxide $\left(\mathrm{SiO}_{2}\right)$ suspension and alpha-casein. The method is based on the property of silicon that binds DNA in the presence of guanidine thiocyanate (Boom et al., 1990; Tartaglia et 
al., 1998). Alpha-casein binds degraded DNA formed as a result of thermal treatment of the meal during production, and is eluted together with DNA in the last step of the isolation (Boom et al., 1999). The samples from which DNA was not isolated were subjected to isolation using the other two methods. The method of isolating DNA according to Słomski (2004) uses $0.2 \mathrm{M} \mathrm{NaOH}$ and $0.04 \mathrm{M}$ Tris-HCl.

In the second stage of the analysis, a sequence characteristic of chickens was amplified by PCR using the starters reported by Lahiff et al. (2001) in accordance with a previously developed method for the identification of the chicken component in feed mixtures.

The product obtained in the PCR reaction was analysed and identified through horizontal electrophoresis in 3\% agarose gel using an X 174 DNA/Hae III marker (1353, 1078, 872, 603, 310, 281, 271, 234, 194, 118 and 72 bp).

DNA bands were visualized under UV light using a camera.

\section{Identification of the bovine component of poultry meals}

In the next stage of the experiment, the results of analysing meals contaminated with bovine meat-and-bone meal were checked. DNA from the samples containing $0.5 \%$ bovine meal was isolated using silica. The obtained DNA was amplified in a PCR reaction using the conditions described for the identification of the bovine component (Natonek et al., 2004).

Determining the sensitivity of the blood meal identification method in feed mixtures

In the final stage of analysis, the sensitivity of the blood meal identification method in feed mixture was determined. For this purpose, feed mixtures containing $0.5,1,2$ and $4 \%$ blood meal were isolated using a Sherlock kit and the DNA obtained in this way was amplified in a PCR reaction using hen starters (Natonek-Wiśniewska et al., 2006).

\section{RESULTS}

Adapting the isolation method to the type of poultry meal

The results of electrophoresis of PCR products using hen starters and DNA obtained by isolation with silica are given in Figure 1. The gel image shows that a 266 bp product, characteristic of the hen component, was obtained for the control mixture (lane 1), poultry meal (lane 2) and feather meal (lane 3). None was obtained for blood meal (lane 4), negative control (lane 5) and water (lane 6).

In another test, poultry blood meal was analysed using a Sherlock kit (A\&A Biotechnology) and the Słomski (2004) method of DNA isolation from blood spots. 

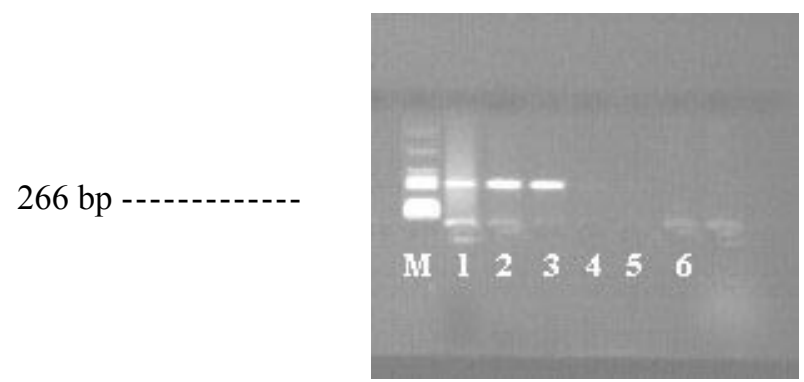

Figure 1. Electrophoresis of PCR products from hen DNA isolated using silica. Successive lanes contain PCR products, with template DNA isolated from: 1. poultry blood, 2. poultry meal, 3. feather meal, 4. poultry blood meal, 5. mixture without bovine meat-and-bone meal, 6. water, $\mathrm{M}$. size marker X 174 DNA/Hae III

Each method was used twice. The results of analysis are given in Figure 2.

The gel image shows the presence of a product characteristic of the hen component for the sample from which DNA was isolated using the Sherlock kit (lanes 2 and 3) and for the positive control (lane 1). No reaction product was obtained when the isolation was performed using the Słomski (2004) method (lanes 4 and 5).

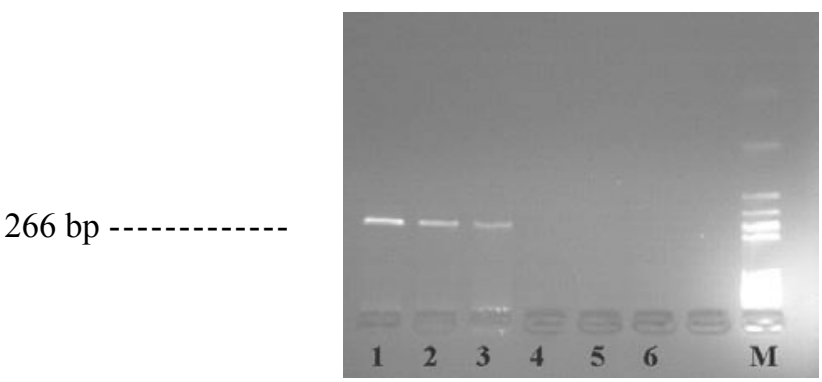

Figure 2. Electrophoresis of PCR products from DNA isolated from poultry $\times 2$ blood meal. Successive lanes contain PCR products, with template DNA isolated from blood meal using: 1. poultry blood, 2. Sherlock kit, 3. Sherlock kit, 4. Słomski method, 5. Słomski method, 6. water, M. size marker X 174 DNA/Hae III

Identification of the bovine component in poultry meals

The result obtained shows (Figure 3 ) that the bovine component was present in all of the analysed samples, as evidenced by the presence of a $271 \mathrm{bp}$ product. 
$271 \mathrm{bp}-\cdot---------$

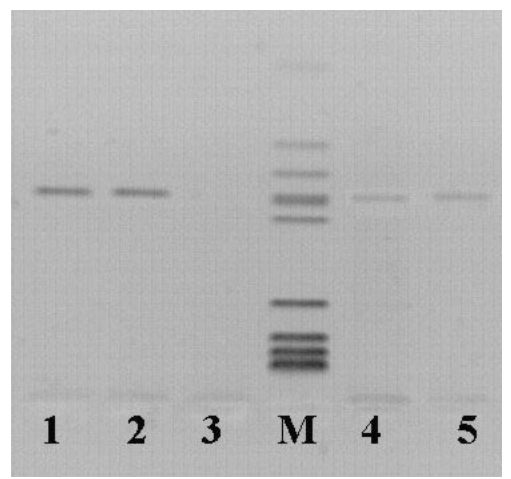

Figure 3. Electrophoresis of PCR products from DNA isolated using silica. Successive lanes contain PCR products obtained using bovine starters and DNA isolated using silica from: 1. poultry and bovine meat-and-bone meal $(0.5 \%), 2$. feed mixture containing bovine meat-and-bone meal, 3. water, 4 . feather meal and bovine meat-and-bone meal $(0.5 \%), 5$. blood meal and bovine meat-and-bone meal (0.5\%), M. size marker X 174 DNA/Hae III

Determining the sensitivity of the blood meal identification method in feed mixtures

The gel image, which illustrates the sensitivity of the method (Figure 4), shows a positive reaction for the mixtures containing $2 \%$ (lane 3 ) and $4 \%$ meal (lane 4 ). Analysis of the mixture containing $0.5 \%$ (lane 1) and $1 \%$ meal (lane 2) did not reveal the reaction product.

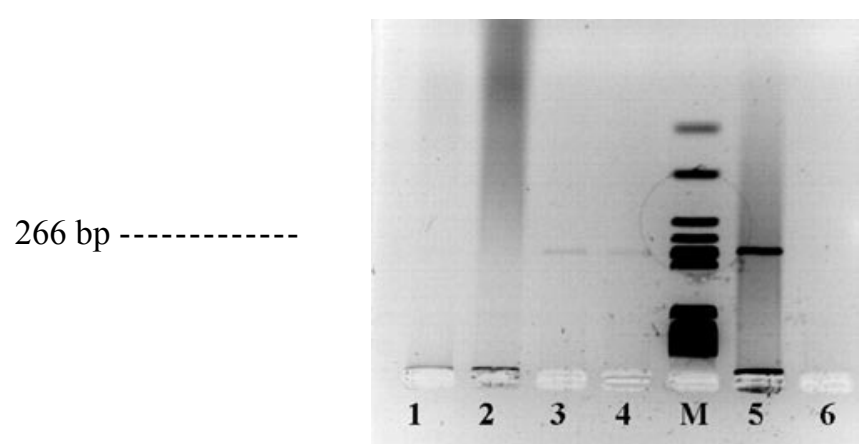

Figure 4. Electrophoresis of PCR products from DNA isolated from feed mixture containing poultry blood meal in amounts of: $1.0 .5 \%, 2.1 \%, 3.2 \%, 4.4 \%, 5$. poultry blood, 6 . water, M. size marker X 174 DNA/Hae III 


\section{DISCUSSION}

The available literature mentions several methods of isolating DNA from meatand-bone meals. For this purpose, laboratory studies have used silica (Boom et al., 1999) or Chelex (Wang et al., 2000) and Blond kits by Qiagen (Tajima et al., 2002). The former has found the widest application thanks to its high sensitivity and relatively low cost. This technique is a modification of the standard method of isolating DNA from hard tissues, which is why, as shown by the studies, it is as effective for meat-andbone meals as for feather meals. However, this method may be inadequate for blood meals. Similarly, the use of this method for isolating DNA from blood spots did not produce satisfactory results. Positive results were obtained only when these samples were analysed using Sherlock kits, which are the standard kits for microtraces.

Analysis of poultry, feather, and blood meals contaminated with bovine meal shows that the methods used are effective for samples containing even small amounts of the banned components.

The sensitivity of the identification method from poultry blood meal was shown to be $2 \%$. Comparison of this result with the sensitivity of the poultry meal identification method $(0.5 \%)$ (Natonek-Wiśniewska et al., 2006) shows that the result obtained for blood meal is less satisfactory. Nevertheless, this is the best method for identifying poultry blood meal.

\section{CONCLUSIONS}

Based the results of this work, the method using silica is most suitable for obtaining DNA from poultry meal and feather meal, whereas the Sherlock kit enables obtaining good DNA yields from poultry blood meals. The use of the developed methods in practice is valuable for BSE prevention and enables poultry meals adulterated with components of other species to be eliminated.

\section{REFERENCES}

Boom R., Cees S., Beld M., Weel J., Goudsmit J., van Dillen PW., 1999. Improved silicaguanidiniumthiocyanate DNA isolation procedure based on selective binding of bovine alphacasein to silica particles. J. Clin. Microbiol. 37, 615-619

Boom R., Sol C.J.A., Salimans M.M.M., Jansen C.L., van Dillen P.M.E., Wertheim J., van der Noordaa J., 1990. Rapid and simple method or purification of nucleic acids. J. Clin. Microbiol. 28, 495-503

Council of the European Communities, 2000. Council decision 2000/766/EC of 4 December 2000 concerning certain protection measures with regard to transmissible spongiform encephalopathies and the feeding of animal protein. Off. J. Eur. Communities L 306, 32-33 
European Parliament and of the Council Communities, 2002. European Parliament and of the Council regulation 2002/1774/EC of 3 October 2002 laying down health rules concerning animal byproducts not intended for human consumption. Off. J. Eur. Communities L 273, 0001-0095

Lahiff S., Glennon M., O’Brien L., Lyng J., Smith T., Maher M., Shilton N., 2001. Species-specific PCR for the identification of ovine, porcine and chicken species in meat and bone meal (MBM). Mol. Cell Probes 15, 27-35

Natonek M., Słota E., Żyga A., Rejduch B., 2004. The utilization of methods based on protein and DNA analysis for identification of animal-origin components in feeds. J. Anim. Feed Sci. 13, 73-76

Natonek-Wiśniewska M., Słota E., Rejduch B., 2006. Methods of detecting animal components in feedstuff (in Polish). Med. wet. 62, 1033-1034

Słomski R. (Editor), 2004. Examples of DNA Analysis (in Polish). The August Cieszkowski Agricultural University, Poznań (Poland), pp. 26

Tajima K., Enishi O., Amari M., Mitsumori M., Kajikawa H., Kurihara M., Yanai S., Matsui H., Yasue H., Mitsuhashi T., Kawashima T., Matsumoto M., 2002. PCR detection of DNAs of animal origin in feed by primers based on sequences of short and long interspersed repetitive elements. Biosci. Biotechnol. Biochem. 66, 2247-50

Tartaglia M., Saulle E., Pestalozza S., Morelli R., Antonucci G., Bataglia P.A., 1998. Detection of bovine mitochondrial DNA in ruminant feeds: A molecular approach to test for the presence of bovine- derived materials. J. Food Protect. 61, 513-518

Wang R., Myers M.J., Campbell W., Cao W., Paine D., Cerniglia C.E., 2000. A rapid method for PCR detection of bovine materials in animal feedstuffs. Mol. Cell Probes 14, 1-5 